\title{
Batrachochytrium dendrobatidis, a novel pathogen approaching endemism in central California
}

\author{
Gretchen E. Padgett-Flohr*, Robert L. Hopkins II \\ Department of Zoology, Southern Illinois University-Carbondale, Carbondale, Illinois 62901, USA
}

\begin{abstract}
The recent emergence of amphibian chytridiomycosis has precipitated competing hypotheses regarding the endemic versus novel nature of the causative agent, Batrachochytrium dendrobatidis $(B d)$. We conducted a retrospective survey of the California Academy of Sciences' (San Francisco, California, USA) amphibian collection, testing for presence of $B d$ in 4 amphibian species collected from central California between 1897 and 2005. The earliest detection of $B d$ was found in 2 Rana catesbeiana in 1961, and the data support the hypothesis that $B d$ was a novel pathogen introduced into central California prior to 1961 that spread out geographically and taxonomically from at least one central location and is now endemic throughout most of central California. The taxonomic pattern of infection prevalence and the ecological constraints of the 4 species we tested suggest that, although $B d$ was initially detected in $R$. catesbeiana, the more efficient and most likely local vector for $B d$ in central California is actually Pseudacris regilla.
\end{abstract}

KEY WORDS: Chytridiomycosis $\cdot$ Batrachochytrium dendrobatidis $\cdot$ Rana draytonii $\cdot$ Natural history collections $\cdot$ Pseudacris regilla $\cdot R$. catesbeiana $\cdot R$. boylii $\cdot$ Co-kriging

Resale or republication not permitted without written consent of the publisher

\section{INTRODUCTION}

Amphibian chytridiomycosis has been implicated as a factor in declines and extinctions of numerous amphibian species (Berger et al. 1998, Carey et al. 1999, Bradley et al. 2002) since its identification in 1998 (Berger et al. 1998). Amphibian chytridiomycosis is caused by infection with Batrachochytrium dendrobatidis $(B d)$, a fungal zoosporic agent (Longcore et al. 1999) with low host specificity (Berger et al. 1998). The recent emergence of this disease has precipitated competing hypotheses regarding the endemic versus novel nature of the pathogen (Daszak et al. 1999, Rachowicz et al. 2005). It has been variously postulated that $B d$ has long been endemic in areas where mortalities, declines and extinctions have been attributed to it but these impacts have only recently been detected, or alternatively, that $B d$ is endemic but has recently become more pathogenic via changes in the agent or changes in host defenses. In contrast, the novel pathogen hypothesis proposes that $B d$ is a newly introduced pathogen parasitizing naïve host species
(Daszak et al. 1999, Rachowicz et al. 2005). Paradoxically, there is support for both hypotheses (Rachowicz et al. 2005); however, this may be because a single hypothesis may not apply at the global level, indicating that investigations into $B d$ emergence need to be undertaken at a smaller regional scale.

Assessing the time line for $B d$ emergence in a particular region necessitates retrospective analysis of amphibian collections, because testing amphibians for $B d$ did not begin until 1998. Museum collections represent an invaluable resource, as the amphibians contained therein provide a unique sampling opportunity, giving present-day researchers an opportunity to assay actual animals (of extant and extinct species) for pathogens across taxa, time, and space. However, retrospective analyses of archived samples have disadvantages as well, largely related to collector bias. Collectors tend to focus on rarer taxa and easily accessed sites, frequently collecting moribund, ill or road-killed animals rather than randomly sampling healthy individuals within a population (Shaffer et al. 1998, Graham et al. 2004, Wandeler et al. 2007). 
Despite these disadvantages, natural history collections nonetheless present our only opportunity for retrospective surveys when seeking answers to questions within an historical context.

Examination of current and archived specimens has documented $B d$ on all continents that harbor amphibians (Bosch et al. 2001, Weldon 2002, Weldon et al. 2004, Une et al. 2008). Weldon et al. (2004) examined 697 archived amphibians collected in South Africa from 1879 to 1999 and detected the earliest known Bd infection in Xenopus laevis collected in 1938. They found that the pathogen was widespread in Africa and concluded that $B d$ was a stable endemic infection in southern Africa for the $23 \mathrm{yr}$ period before $B d$ was first detected on another continent. Their museum survey results formed the basis for the hypothesis that $B d$ originated in Africa and supported the proposal that $X$. laevis was most likely the original global vector of the pathogen. X. laevis was globally exported out of Africa beginning in 1935, when it became the test species used for human pregnancy assays (Tinsley \& McCoid 1996). Rana catesbeiana has also been postulated as a global vector of $B d$ (Daszak et al. 2004, Garner et al. 2006, Fisher \& Garner 2007), as both $R$. catesbeiana and $X$. laevis are relatively asymptomatic when infected (Parker et al. 2002, Daszak et al. 2004) and both species are globally transported for the pet, food and laboratory trades (Tinsley \& McCoid 1996, Cunningham et al. 2003, Daszak et al. 2004, Fisher \& Garner 2007).

The earliest known $B d$-positive specimens outside of Africa were 2 Rana clamitans collected in July 1961 in Quebec, Canada, as documented by Ouellet et al. (2005), who surveyed amphibian collections from 2 Canadian museums spanning 1895 to 1990. They assayed amphibians for $B d$ on a global basis, testing specimens from 25 countries. Through their retrospective broad-scale analysis they also showed that $B d$ infection has been present in the USA since at least 1975, documenting its occurrence in 7 states in the USA within the interval 1975 to 2001 (Ouellet et al. 2005). This finding has recently been updated by Longcore et al. (2007), who found that $B d$ has been present in northeastern USA since at least 1961.

Although $B d$ has been linked to population declines and extinctions in native anurans in Panama (Pounds et al. 1997, Lips 1998, 1999), Australia (Berger et al. 1998) and the United States (Rana chiricahuensis, $R$. yavapiensis: Bradley et al. 2002; R. pipiens: Morell 1999; R. muscosa: Rachowicz et al. 2006), Bd is not the exclusive causative agent for all global declines. For example, Daszak et al. (2005) tested for Bd in archived amphibians collected over a 61 yr span (1940-2001) at wetlands on the Savannah River Site, South Carolina, USA. The pathogen was detected in 2 R. catesbeiana and a single $R$. sphenocephala (3/137; $2.18 \%)$ collected between 1978 and 1981. Their analysis of local anuran populations showed that 4 species including $R$. sphenocephala declined significantly over the $61 \mathrm{yr}$; however, they found that declines were associated with drying trends at the site rather than $B d$ infection (Daszak et al. 2005). Longcore et al. (2007) found that, although $B d$ is widespread in the northeastern USA, there has been no evidence of $B d$-related declines. Despite the obvious contributions of museum surveys encompassing whole countries or continents, few researchers have studied archived samples collected from specific sites such as was done for the Savannah River Site.

Our goal was to search for evidence of $B d$ emergence in central California by conducting a retrospective survey of the California Academy of Sciences' ([CAS] San Francisco, California, USA) amphibian collection. We present information on the geographic and taxonomic distribution of the pathogen through time and provide support for the novel-pathogen hypothesis of $B d$ emergence in central California. In addition, we evaluated the data to assess which species of the 4 tested would be the most likely local vector for $B d$ in central California.

\section{MATERIALS AND METHODS}

Amphibian collection. We randomly sampled 687 anurans of Rana boylii, R. catesbeiana, R. draytonii and Pseudacris regilla opportunistically collected between 1897 and 2005 from central California. We restricted our samples to these 4 taxa, as these species historically had a broad distribution within the state which would allow us to document $B d$ occurrence across the large geographic area of central California. We restricted our geographic sampling region to the 40 counties that roughly constitute central California. Samples in the museum were arranged by species with no categorization by county or date of collection, and we randomly pulled samples of our target taxa, ensuring that samples we retained for assay were collected from one of the 40 counties. All individuals were formalin-fixed, ethanol-preserved specimens from the CAS Herpetological Collection located in Golden Gate Park, San Francisco, California, USA.

Histological examination. We excised a small patch of epidermal tissue (approximately $3 \times 3 \mathrm{~mm}$ ) from the inner thigh of each anaran and stored the samples in $70 \%$ ethanol. Tissues were paraffin-embedded, serialsectioned in $5 \mu \mathrm{m}$ increments and haematoxylin-eosin stained for examination under light microscopy. We coded the slides with the CAS accession numbers only and examined slides blind with no knowledge of date 
of collection or species. We diagnosed $B d$ infection when we were able to observe thalli or zoosporangia in the stratum corneum - stratum germinosum layers of the epidermis. When diagnosis was based on few or a single thallus, we confirmed identification by sending photomicrographs of the structures to Allan Pessier for verification and by repeating histological preparation using Grocott methenamine silver nitrate (GMS) staining to further differentiate $B d$ thalli from the surrounding tissue (Fig. 1).

Data analysis. We used SAS/STAT ${ }^{\circledR}$ software, Version 9.1.2 for Windows to conduct a logistic regression analysis $(\alpha=0.05)$ to test the hypotheses that $B d$ infection prevalence was independent of species or decade.

Maps of all sample localities were created in ArcGIS 9.2 and coded according to results from the pathogen screening. We created spatio-temporal distribution maps of pathogen occurrences using all positive sites. Four temporal classes were generated using natural breaks in the data. We then plotted positive sites of each species keeping temporal classes consistent between maps to facilitate comparison.

We applied a co-kriging technique to the data to visualize spatio-temporal trends of pathogen occurrence. Co-kriging is an interpolation technique using patterns of autocorrelation and cross-correlation between 2 or more datasets to predict values across a surface (Heisel et al. 1999). Universal kriging, which assumes an undefined trend surface, was applied to each dataset for interpolation. Because data were restricted to samples from the CAS, predictions were smoothed to account for uncertainty. This produces a more conservative interpolation and trend estimate.
We co-kriged 2 data sets; all positive sites and a modified dataset with points removed to extract trend data. In the latter case, we created a map in which data points from each temporal class was enclosed with a polygon and stacked with the oldest layer on top. Data contained in the polygons were mutually exclusive in overlap areas with the oldest points receiving priority. Essentially, any points within an overlapping area not belonging to the oldest temporal class in that area were removed. Our reasoning was based on the realization that once a positive occurrence is detected in an area it is expected that positive occurrences in that area will continue to be detected. We co-kriged these data with data from all positive sample sites to avoid bias in the data and account for relative frequencies of pathogen occurrences in each temporal class. The output is a hybridization of the 2 interpolated surfaces and helps account for spatial outliers and clustering in the base dataset (Heisel et al. 1999). Because of gaps in the raw data, the temporal contours were not constrained to be equal; this better revealed general pathogen trends in central California.

\section{RESULTS}

We sampled $19.2 \%(687 / 3556)$ of the CAS collection of Rana boylii, $R$. catesbeiana, $R$. draytonii and Pseudacris regilla opportunistically collected between 1897 and 2005 in central California (Table 1). We detected $B d$ infection in 91 of the 687 (13.2\%) amphibians we sampled (Table 1, Fig. 2) and found the earliest infections in $2 R$. catesbeiana (Table 1) collected in 1961
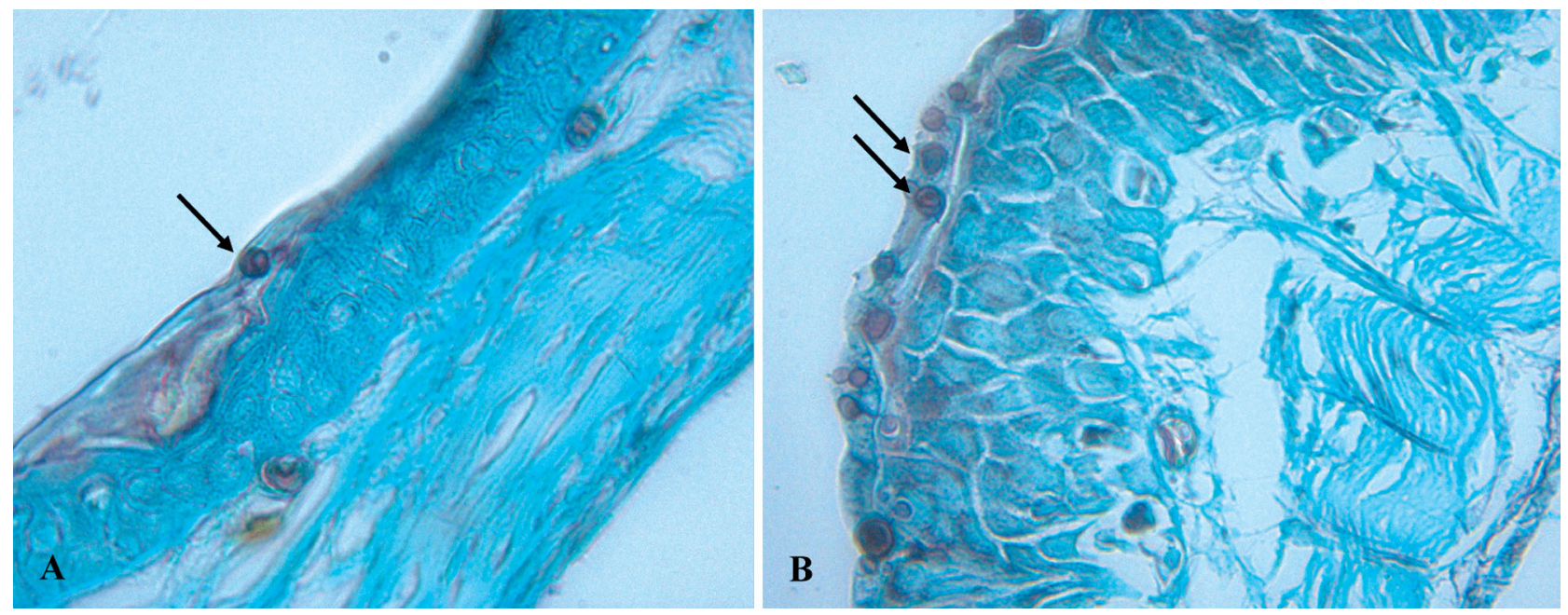

Fig. 1. Batrachochytrium dendrobatidis ( $B d$ ) infecting Rana catesbeiana and $R$. boylii. Grocott methenamine silver nitrate (GMS)stained $5 \mu \mathrm{m}$ sections of the inner thigh of (A) California Academy of Sciences (CAS) \#20242 R. catesbeiana collected in 1961 from Lake Lagunitas, Palo Alto, CA, USA, and (B) CAS \#22053 R. boylii collected in 1966 from Arroyo Mocho, Alameda County, CA. Arrows point to $B d$ thalli 


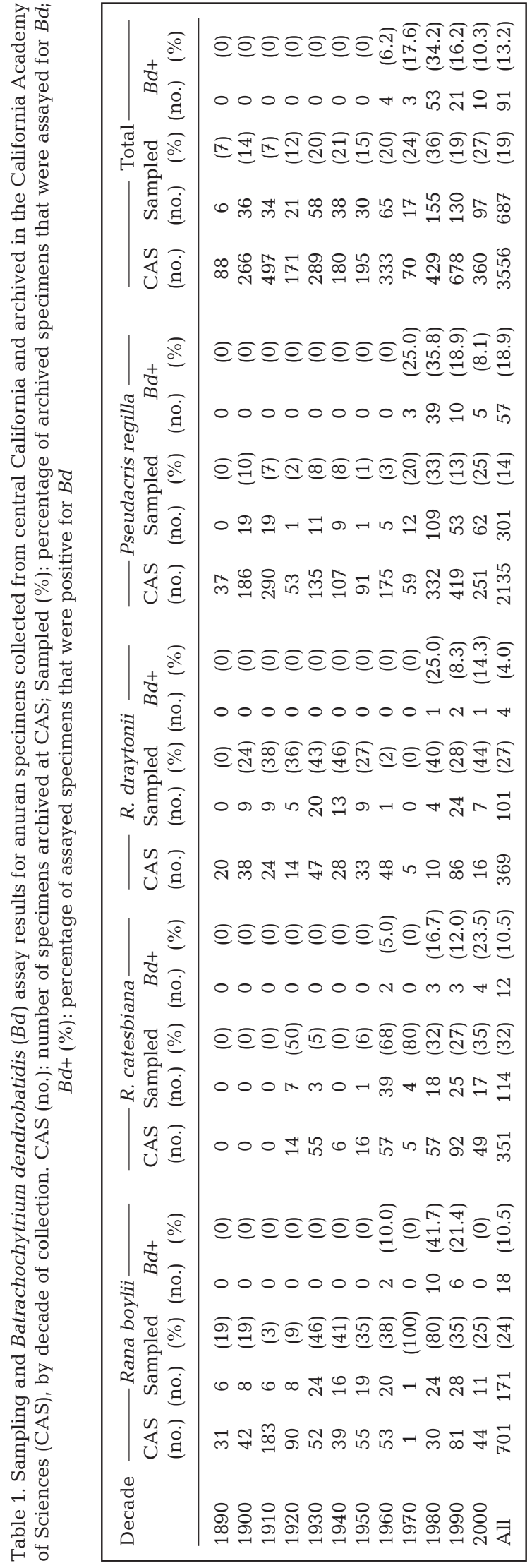

from Lake Lagunitas on the Stanford University Campus in Palo Alto, Santa Clara County. The next earliest infections we found were from $2 R$. boylii, both collected in 1966: one individual was collected from Bear Creek in Santa Cruz county, 20 miles $(32.2 \mathrm{~km})$ due south of Lake Lagunitas, and the other was collected 50 miles $(80.5 \mathrm{~km})$ east of Lake Lagunitas in the Arroyo Mocho waterway in southeastern Alameda county (Fig. 3). Bd infection was not detected in any of the 223 sampled amphibians collected prior to 1961 (Table 1). Geostatistical analysis of all positive samples (Fig. 4) shows that $B d$ was apparently introduced prior to or around 1961 in Santa Clara County located in the San Francisco Bay Area and spread radially north, south and east across central California over the next $\geq 40 \mathrm{yr}$.

Logistic regression analysis showed that $B d$ infection was most frequent in Pseudacris regilla $\left(\chi^{2}=4.6257\right.$, $\mathrm{df}=1, \mathrm{p}=0.0315$ ) (Fig. 3), and that infection prevalence was highest in the interval 1980-1989 $\left(\chi^{2}=\right.$ 15.4766, df $=1, \mathrm{p}<0.0001$ ).

\section{DISCUSSION}

We found that $B d$ has been in central California since at least 1961, although this may be a conservative estimate because histological examination is highly specific but less sensitive than PCR in detecting the pathogen (Retallick et al. 2004, Ouellet et al. 2005, Kriger et al. 2006). Furthermore, sample sizes for some counties and/or decades were small, which reduced our statistical power and could have biased our results. Collectors contributing to museums frequently tend to target particular species, and often the focus is the rarer taxa rather than the more common ones, resulting in non-random sampling (Petersen \& Meier 2003). Collected amphibians are oftentimes road-killed (e.g. Longcore et al. 2007), dead, moribund or in obvious ill health and thus do not represent a true random sampling of a population. In addition, areas sampled tend to be those that are most easily accessed such as near roads, towns and biological stations, or are the favored locality of the collector (Shaffer et al. 1998, Graham et al. 2004, Wandeler et al. 2007). These collector biases, therefore, result in small sample sizes for certain taxa and most notably geographic gaps in available archived samples, requiring investigators to view research results with caution. There are also constraints via time periods in which collections were infrequently conducted due to historical events such as World Wars or the date in which a particular museum was established. For example, the vast majority of the CAS Natural History Collection was destroyed in the San Francisco 1906 earthquake; thus, there is little representation of the decades prior to 1900, which may have constrained or biased our results. 
If the current hypotheses of $\mathrm{Bd}$ originating in Xenopus laevis in South Africa and subsequent global dissemination via intercontinental exportation are correct, our earliest detection of $B d$ in central California would be consistent with the first global exportations of South African X. laevis for the pet trade, laboratory trade, and for use in pregnancy testing (Weldon et al. 2004). X. laevis was first shipped to the US in 1949, and it is reasonable to assume that the species would have been shipped to institutions such as Stanford University, which hosts both a research facility and medical center. $B d$-infected $X$. laevis could have either escaped or been released into Lake Lagunitas at some point in the interval (1949-1961), thereby introducing the pathogen and infecting resident anurans.

Our estimates of $B d$ prevalence and year of first detection were also consistent with the findings of Ouellet et al. (2005), who found an overall prevalence of $13.1 \%$ in anurans collected within North America between 1895 and 2001. In addition, their study found $7.0 \%$ prevalence in the $1960 \mathrm{~s}$ and we found $6.0 \%$ prevalence in central California in the 1960s. Ouellet et al. (2005) concluded that $B d$ was not likely a new pathogen, but it is unclear from their comments whether this statement may be interpreted to mean that their study supports the endemic pathogen hypothesis or if they are merely stating that, in the context of current times, $B d$ is not a 'new' pathogen since it is documented to have been present in the USA for at least 4 decades.

We believe that our findings are most consistent with the hypothesis that $B d$ is a novel pathogen introduced in the San Francisco Bay Area (Santa Clara County) in the 1950s or early 1960s, as we did not obtain any positive samples prior to 1961. Lack of a positive finding does not prove the negative, however, and it is possible that increasing our sample sizes by including samples from other museums might change the outcome and thus our conclusions. Including additional amphibian species could also impact our findings; however, the majority of the remaining amphibian species in California occur within highly restricted distributions in the state and thus cannot be analyzed across the large geographic region we examined. It seems reasonable to assume that transmission of a pathogen across large contiguous geographic regions of multiple habitats would require vector species whose distributions span the region. Museum sampling was geographically constrained because some counties, particularly in the Sierra Nevada Mountain Range, had little or no representation of the 4 target species within the CAS collection. Based on the available data from the 4 species we tested, we found that $B d$ appears to have spread in a radial pattern through central California from an initial central location over a period of $40 \mathrm{yr}$.

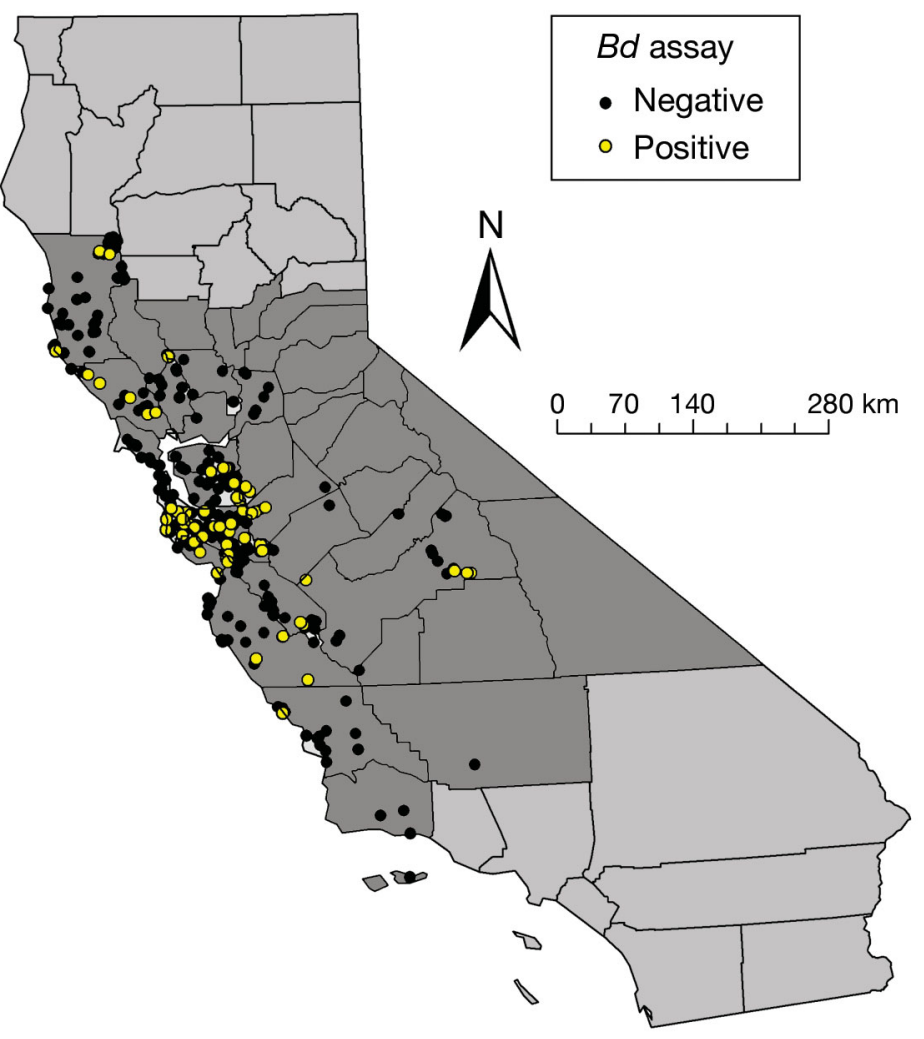

Fig. 2. ArcGIS-mapped assay results of Batrachochytrium dendrobatidis $(B d)$ testing for California Academy of Sciences museum samples of Rana boylii, $R$. catesbeiana, $R$. draytonii and Pseudacris regilla collected between 1897 and 2005 from central California. Counties considered to constitute central California are shaded in dark gray

Evaluating other species with more restricted ranges from central California may identify additional central areas of $B d$ emergence. Green \& Sherman (2001) detected $B d$ in 2/21 Bufo canorus toads collected during a die-off event in the eastern Sierra Nevada mountains of California in 1976 to 1979. We suggest the possibility that $B d$ introduction could have occurred in disparate locations but that the demographic and environmental conditions conducive to the establishment and spread of the disease may not have been present in all localities. Expansion of an introduced organism requires successful transport and establishment, properties that are conferred by local demographic conditions (Johnson \& Padilla 1996). For example, Ayres et al. (2004) found that invasive Spartina sp. expanded radially from a central core population. Although isolated disparate establishments of Spartina sp. were present within their sample area, they found that the expansion of the exotic cordgrass was primarily characterized by the dynamics of a few select populations (Ayres et al. 2004). We hypothesize this may be reflected in the situation with the estab- 


\section{Rana boylii}

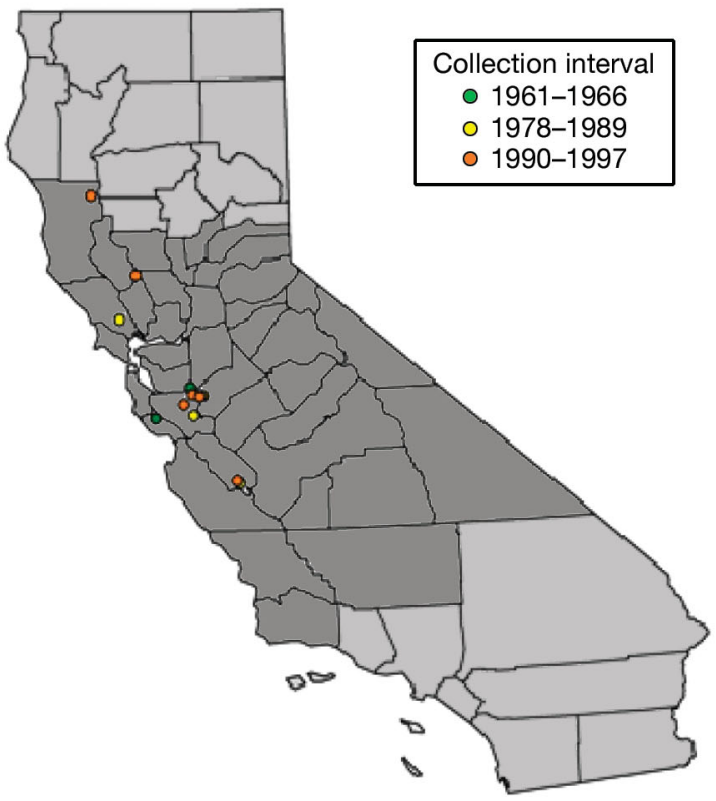

Rana draytonii
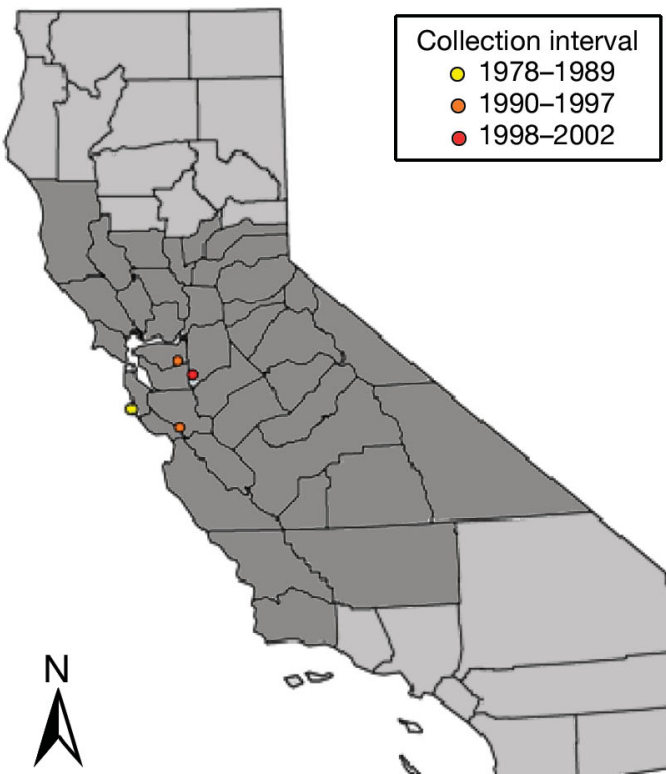

075150

\section{Rana catesbeiana}

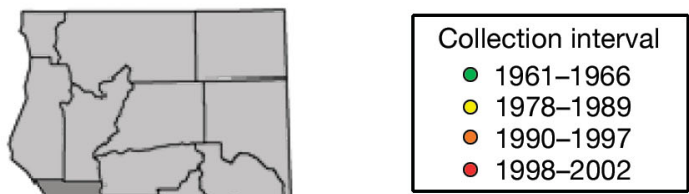

\section{Pseudacris regilla}

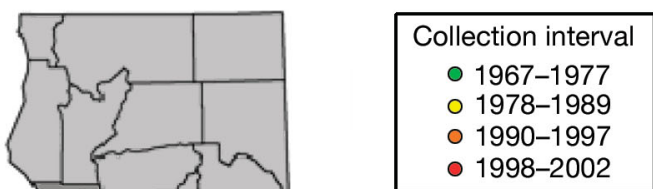

Fig. 3. Individual ArcGIS maps of positive Batrachochytrium dendrobatidis $(B d)$ results by species and time interval for all 4 species surveyed from California Academy of Sciences museum (Rana boylii, $R$. catesbeiana, R. draytonii and Pseudacris regilla). The positive sites of each species were plotted with temporal classes kept consistent between maps to facilitate comparison. Counties considered to constitute central California are shaded in dark gray 
lishment and expansion of $B d_{\text {; thus, our model }}$ does not preclude the possibility of satellite occurrences of $B d$ but does suggest a lesser role of these occurrences in the expansion of $B d$ in central California.

Any amphibian species that can be infected but remain asymptomatic is a potential vector for $B d$. On a global scale, the hypothesis of Rana catesbeiana and Xenopus laevis as vectors has merit as both species (1) are globally transported for the food, pet, and laboratory research trades (Cunningham et al. 2003, Daszak et al. 2004, Weldon et el. 2004, Fisher \& Garner 2007); (2) are apparently susceptible to infection but remain asymptomatic relative to a disease state (Weldon 2002, Daszak et al. 2004, Weldon et al. 2004, Blaustein et al. 2005); and (3) often escape into or are released into non-native environments (Tinsley \& McCoid 1996, Crayon 2005). On a local scale, however, once outside their native habitats, the species' potential for dispersal, and thus the potential for long-distance geographic vectoring of pathogens, is constrained by their ecological requirements. Both species are highly aquatic and overland migration is restricted to periods of intense rainfall (Tinsley \& McCoid 1996, Crayon 2005). In addition, both aestivate in the bottoms of lakes and ponds during winter. $R$. catesbeiana adults remain inactive until water temperatures approach $15^{\circ} \mathrm{C}$ (Harding 1997). Established populations of $X$. laevis are known to occur in southern California, but there is no evidence of established populations in central California (Crayon 2005). R. catesbeiana is established throughout much of the state but does not generally persist at sites above $1800 \mathrm{~m}$ due to cooler temperatures. $R$. catesbeiana apparently will only disperse during summer in response to adverse or drought conditions (Jameson 1956), and rarely travel more than $3 \mathrm{~km}$ when seeking out new suitable aquatic habitat (Willis et al. 1956).

At local and regional scales, Pseudacris regilla is probably a superior vector to either Xenopus laevis or Rana catesbeiana. $P$. regilla is susceptible to infection but remains asymptomatic (Blaustein et al. 2005, G. PadgettFlohr unpubl. data). $P$. regilla is more broadly distributed in California than any other native amphibian species, absent only from the Mojave Desert, and occurs at all elevations from sea level up to the Alpine-Arctic regions. In the Sierra Nevada, P. regilla is the most common amphibian encountered at elevations above $2440 \mathrm{~m}$ (Jennings et al. 1992) and further is described as the most abundant amphibian wherever it occurs (Rorabaugh \& Lannoo 2005). The range of the species encompasses the majority of California, all of Oregon, Washington,

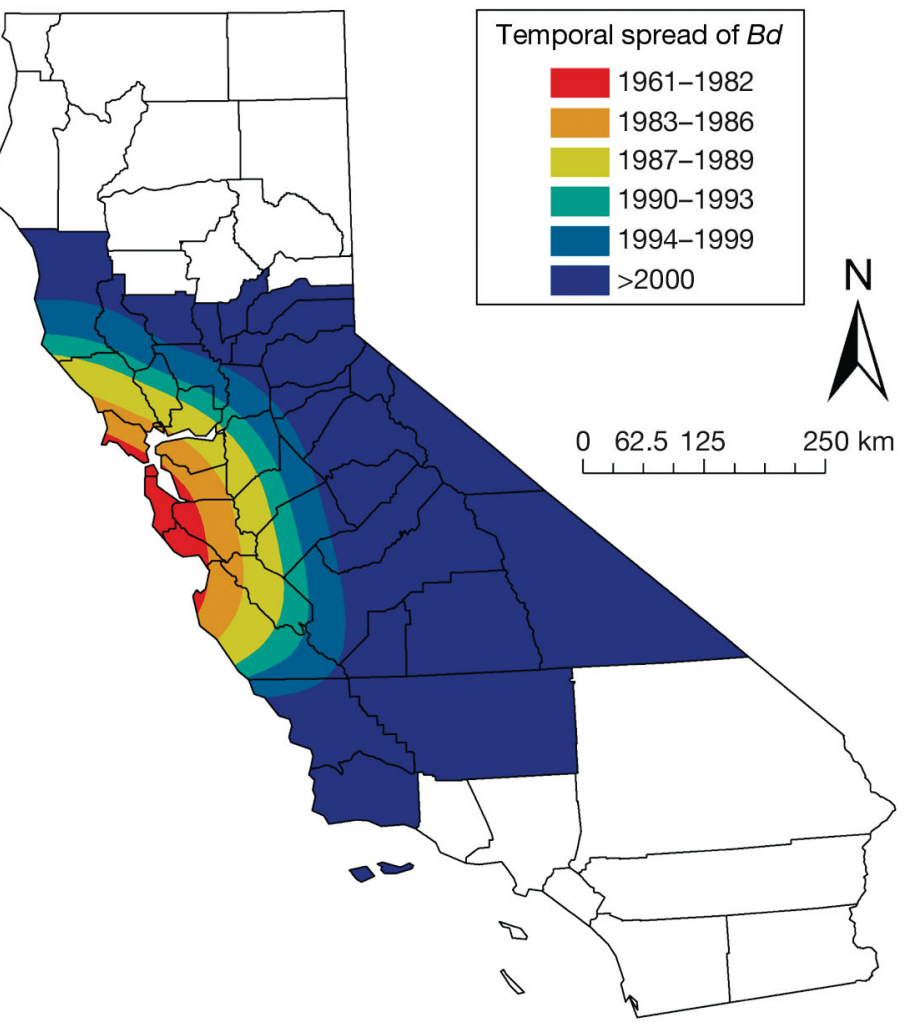

Fig. 4. Batrachochytrium dendrobatidis $(B d)$. Spatio-temporal distribution of $B d$ occurrences in California 1961-2005 were created using all positive sites. Six temporal classes were generated using natural breaks in the data

Nevada, and portions of Idaho, Montana, Utah, Arizona, and Baja California. P. regilla remains active even at $4^{\circ} \mathrm{C}$ and is freeze-tolerant (Croes \& Thomas 2000). Home ranges are large, encompassing upland foraging sites, aestivation sites, breeding ponds and movement corridors between ponds (Schaub \& Larsen 1978).

Some species of treefrogs seem to be highly resilient to desiccation, cold and deprivation and have a high potential for unintentional anthropogenic dispersal as demonstrated by 2 live individuals that were inadvertently included in shipments of mulch (Zippel 2005a,b). Therefore, Pseudacris regilla would appear to be the most suitable vector across habitats in California, and in our study the preponderance of spatio-temporal data on $B d$ occurrences in this species drives our geostatistical analysis, suggesting that the taxon may be a more suitable local vector of $B d$ than the other species tested (Fig. 3).

In summary, the spatio-temporal pattern of $B d$ prevalence in archived anuran specimens in our study supports the hypothesis that $B d$ was a novel pathogen introduced into central California around 1961 that spread out geographically in a radial pattern. These data also indicate that $B d$ is now endemic throughout 
most of central California, although the trend analysis indicates that $B d$ is still spreading radially outward and thus will likely be a novel pathogen infecting naïve populations for some time to come as the pathogen advances. The taxonomic pattern of infection prevalence and ecological constraints of the 4 species tested also suggests that, although $B d$ was initially detected in Rana catesbeiana, the more efficient and most likely vector for $B d$ in central California is actually Pseudacris regilla. As disease ecology becomes more integrated into conservation biology, new diseases will likely be discovered and retrospective analysis will be invaluable as it represents the only opportunity to track the taxonomic, temporal, and geographic spread of a newly recognized pathogen.

Acknowledgements. We extend our sincere gratitude and appreciation to the California Academy of Sciences, San Francisco, California for allowing G.E.P.F. to sample their amphibian collection. We thank R. Drewes for his encouragement, support and enthusiasm for this project and J. Vindum for his assistance with delving into the collection. We extend our appreciation to M. Doran, C. Bailey and D. Grisley in the histology lab at Southern Illinois University-Carbondale. We further thank M. Whiles for encouraging the senior author to conduct this study as part of her $\mathrm{PhD}$ research and for providing the equipment necessary to complete this work. G.E.P.F. also thanks J. E. Longcore for training and guidance and A. Pessier for providing advice and verification of infections in some animals. We thank E. Schauber for guidance in this project and for reviewing all drafts of this manuscript. Partial funding for this project was provided by the National Science Foundation's BRIDGE to the Doctorate program and the Department of Zoology, Southern Illinois University-Carbondale.

\section{LITERATURE CITED}

Ayres DR, Smith DL, Zaremba K, Klohr S, Strey DR (2004) Spread of exotic cordgrasses and hybrids (Spartina sp.) in the tidal marshes of San Francisco Bay, California, USA. Biol Invasions 6:221-231

> Berger L, Spear R, Daszak P, Green DE and others (1998) Chytridiomycosis causes amphibian mortality associated with population declines in the rain forests of Australia and Central America. Proc Natl Acad Sci USA 95:9031-9036

Blaustein AR, Romansic JM, Scheessele EA, Han BA, Pessier AP, Longcore JE (2005) Interspecific variation in susceptibility of frog tadpoles to the pathogenic fungus Batrachochytrium dendrobatidis. Conserv Biol 19:1460-1468

Bosch J, Martinez-Solano I, Garcia-París M (2001) Evidence of a chytrid fungus infection involved in the decline of the common midwife toad (Alytes obstetricans) in protected areas of central Spain. Biol Conserv 97:331-337

Bradley GA, Rosen PC, Sredl MJ, Jones TR, Longcore JE (2002) Chytridiomycosis in native Arizona frogs. J Wildl Dis 38:206-212

> Carey C, Cohen N, Rollins-Smith LA (1999) Amphibian declines: an immunological perspective. Dev Comp Immunol 23:459-472

Crayon JJ (2005) Family Pipidae: Xenopus laevis. In: Lannoo M (ed) Amphibian declines. University of California Press, Berkeley and Los Angeles, CA, p 522-526
Croes SA, Thomas RE (2000) Freeze tolerance and cryoprotectant synthesis of the Pacific treefrog Hyla regilla. Copeia 2000:863-868

Cunningham AA, Daszak P, Rodriguez JP (2003) Pathogen pollution: defining a parasitological threat to biodiversity conservation. J Parasitol 89(Suppl):S78-S83

Daszak P, Berger L, Cunningham AA, Hyatt AD, Green DE, Speare R (1999) Emerging infectious diseases and amphibian population declines. Emerg Inf Dis 5:735-748

Daszak P, Strieby A, Cunningham AA, Longcore JE, Brown CC, Porter D (2004) Experimental evidence that the bullfrog (Rana catesbeiana) is a potential carrier of chytridiomycosis, an emerging fungal disease of amphibians. Herpetol J 14:201-207

Daszak P, Scott DE, Kilpatrick AM, Faggioni C, Gibbons JW, Porter D (2005) Amphibian population declines at Savannah River site are linked to climate, not chytridiomycosis. Ecology 86:3232-3237

Fisher MC, Garner TWJ (2007) The relationship between the emergence of Batrachochytrium dendrobatidis, the international trade in amphibians and introduced amphibian species. Fungal Biol Rev 21:2-9

> Garner TWJ, Perkins MW, Govindarajulu P, Seglie D, Walker S, Cunningham AA, Fisher MC (2006) The emerging pathogen Batrachochytrium dendrobatidis globally infects introduced populations of the North American bullfrog, Rana catesbeiana. Biol Lett 2(3):455-459

Graham CH, Ferrier S, Huettman F, Moritz C, Peterson AT (2004) New developments in museum-based informatics and applications in biodiversity analysis. Trends Ecol Evol 19:497-503

> Green DE, Sherman CK (2001) Diagnostic histological findings in Yosemite toads (Bufo canorus) from a die-off in the 1970s. J Herpetol 35:92-103

Harding JH (1997) Amphibians and reptiles of the Great Lakes region. University of Michigan Press, Ann Arbor, $\mathrm{MI}$

> Heisel T, Ersboll AK, Anreasen C (1999) Weed mapping with co-kriging using soil properties. Precis Agric 1:39-52

Jameson DL (1956) Survival of some central Texas frogs under natural conditions. Copeia 1956:55-57

Jennings WB, Bradford DF, Johnson DF (1992) Dependence of the garter snake Thamnophis elegans on amphibians in the Sierra Nevada of California. J Herpatol 26:503-505

> Johnson LE, Padilla DK (1996) Geographic spread of exotic species: ecological lessons and opportunities from the invasion of the zebra mussel Dreissema polymorpha. Biol Conserv 78:23-33

Kriger KM, Hines HB, Hyatt AD, Boyle DG, Hero JM (2006) Techniques for detecting chytridiomycosis in wild frogs: comparing histology with real-time Taqman PCR. Dis Aquat Org 71:141-148

> Lips KR (1998) Decline of a tropical montane amphibian fauna. Conserv Biol 12:106-117

Lips KR (1999) Mass mortality and population declines of anurans at an upland site in western Panama. Conserv Biol 13:117-125

Longcore JE, Pessier AP, Nichols DK (1999) Batrachochytrium dendrobatidis gen. et sp. nov., a chytrid pathogenic to amphibians. Mycologia 91:219-227

> Longcore JR, Longcore JE, Pessier AP, Halteman WA (2007) Chytridiomycosis widespread in anurans of northeastern United States. J Wildl Manag 71:435-444

Morell V (1999) Are pathogens felling frogs? Science 284:728-731

Ouellet M, Mikaelian I, Pauli BD, Rodrigue J, Green DM (2005) Historical evidence of widespread chytrid infection 
in North American amphibian populations. Conserv Biol 19:1431-1440

Parker JM, Mikaelian I, Hahn N, Diggs HE (2002) Clinical diagnosis and treatment of epidermal chytridiomycosis in African clawed frogs (Xenopus tropicalis). Comp Med 52:265-268

Petersen FT, Meier R (2003) Testing species-richness estimation methods on single-sample collection data using the Danish diptera. Biodivers Conserv 12:667-686

Pounds JA, Fogden MPL, Savage JM, Gorman GC (1997) Test of null models for amphibian declines on a tropical mountain. Conserv Biol 11:1307-1322

Rachowicz LJ, Hero JM, Alford RA, Taylor JW and others (2005) The novel and endemic pathogen hypothesis: competing explanations for the origin of emerging infectious diseases of wildlife. Conserv Biol 19:1441-1448

Rachowicz LJ, Knapp RA, Morgan JAT, Stice MJ, Vredenburg VT, Parker JM, Briggs CJ (2006) Emerging infectious dissease as a proximate cause of amphibiam mass mortality. Ecology 87:1671-1683

Retallick RWR, McCallum H, Speare R (2004) Endemic infection of the amphibian chytrid fungus in a frog community post-decline. PLoS Biol 2:e351

Rorabaugh JC, Lannoo MJ (2005) Pseudacris regilla, Pacific treefrog. In: Lannoo M (ed) Amphibian declines. University of California Press, Berkeley and Los Angeles, CA, p 478-484

Editorial responsibility: Alex Hyatt,

Geelong, Victoria, Australia
Schaub BJ, Larsen JH (1978) The reproductive ecology of the Pacific treefrog (Hyla regilla). Herpetologica 34:409-416

Shaffer HB, Fisher RN, Davidson C (1998) The role of natural history collections in documenting species declines. Trends Ecol Evol 13:27-30

Tinsley RC, McCoid MJ (1996) Feral populations of Xenopus outside Africa. In: Tinsley RC, Kobel HR (eds) The biology of Xenopus. Clarendon Press, Oxford, p 81-94

> Une Y, Kadekaru S, Tamukai K, Goka K, Kuroki T (2008) First report of spontaneous chytridiomycosis in frogs in Asia. Dis Aquat Org 82:157-160

Wandeler P, Hoeck EA, Keller LF (2007) Back to the future: museum specimens in population genetics. Trends Ecol Evol 22:634-642

Weldon C (2002) Chytridiomycosis survey in South Africa. Froglog 51:1-2

Weldon C, du Preez LH, Hyatt AD, Muller R, Speare R (2004) Origin of the amphibian chytrid fungus. Emerg Infect Dis 10:2100-2105

> Willis YL, Moyle DL, Baskett TS (1956) Emergence, breeding, hibernation, movements and transformation of the bullfrog, Rana catesbeiana, in Missouri. Copeia 1956:30-41

Zippel KC (2005a) Eleutherodactylus planirostris (greenhouse frog); cold tolerance. Herpetol Rev 36:299-300

Zippel KC (2005b) Hyla chrysoscelis (gray treefrog); deprivation tolerance. Herpetol Rev 36:301-330

Submitted: April 11, 2008; Accepted: October 27, 2008

Proofs received from author(s): January 25, 2009 